\section{Lettlest om fot- og ankelkirurgi}

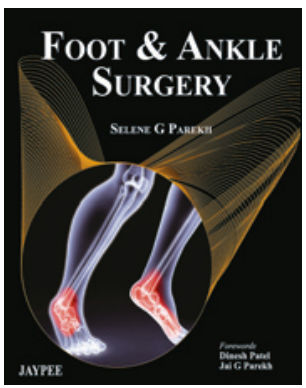

Selene G. Parekh

Foot and ankle surgery

548 s, tab, ill. London: JP Medical, 2012.

Pris GBP 90

ISBN 978-93-5025-787-6

Flere internasjonale kapasiteter innen fot- og ankelkirurgi har bidratt til de 25 kapitlene i boken. Innholdet dekker et bredt spekter innen feltet.

Inndelingen er lik de fleste andre bøker om dette temaet. De første kapitlene omhandler undersøkelsesteknikker og kirurgisk fot-ankel-anatomi. Dernest beskrives behandling av tilstander i tærne. Hallux valgus-kirurgi er en av de vanligste prosedyrene innen fotkirurgi - følgelig er den viet et eget kapittel som gir et godt overblikk over de mest aktuelle metodene. Siden boken er utgitt i 2012, kunne den også ha inkludert noen nyere teknikker som ligamentær forsterkning, f.eks. «tightrope»-systemet.

Kapitlene om nevrologiske tilstander i foten og hælsmerter inneholder fornuftige tilnærminger til disse problemstillingene, som av og til kan være vanskelige å diagnostisere og behandle. Omtalen av fottumorer er holdt relativt kort, noe som er passende for en bok som denne som tross alt er rettet mot ortopediske kirurger som driver med «generell» fotkirurgi. Det gis en grundig gjennomgang av artrose i fot og ankel, med forslag til både konservativ og operativ behandling. I boken er det hovedsakelig forfatternes metode som er presentert. For en mer nyansert beskrivelse skulle andre fiksasjonsmetoder også vært med, som for eksempel artrodese med margnagling.

Innholdet i kapitlene om pes planus, pes cavus og senepatologi er godt og ikke for detaljert. Nivået passer for ortopeder som ønsker kunnskap om tilstandene, men ikke trenger inngående operasjonsanvisninger. Avsnittet om operativ behandling av akillessenerupturer var imidlertid skuffende. Tilstanden er såpass vanlig at den hadde fortjent en ordentlig gjennomgang med illustrasjoner av diverse surturteknikker.

Fremstillingen av den diabetiske foten, den nevropatiske foten, ortoser, proteser, amputasjoner i fot og ankel, idrettsskader og stressfrakturer i foten vil være nyttig informasjon for ortopeder i utdanning. Leseren får en adekvat oversikt over artroskopi, men de som ønsker å drive med ankelartroskopi vil behøve en egen bok om emnet. Tre kapitler mot slutten gir relevant informasjon om pediatriske fottilstander, kort omtale av komplekst regionalt smertesyndrom og beskrivelse av vanlige infeksjonstilstander i foten. Det siste kapitlet om fot- og ankeltraumer er på kun 14 sider, følgelig gir det bare en enkel oversikt over de vanligste skadene.

Totalinntrykket er godt. Boken er innbundet og har behagelig papirkvalitet. Illustrasjonene, spesielt de fotografiske, er til dels svært gode. I nesten alle kapitlene gir forfatterne en god gjennomgang av «the authors preferred method». Noen av metodene er nøye beskrevet og til dels meget godt illustrert. Det finnes ingen bok om fot- og ankelkirurgi som dekker alle behov, så vi må plukke ut rosinene fra forskjellige lærebøker. Foot and ankle surgery inneholder noen rosiner. Den konkurrerer imidlertid med en rekke andre fotkirurgibøker, deriblant noen som er meget gode. Denne kan ikke sammenliknes med de mest etablerte på markedet som kommer i flere bind. Jeg kan likevel anbefale denne boken, spesielt til ortopeder som skal begynne med fotkirurgi. Kapitlene er lettleste og man drukner ikke i detaljer. Prisen sett mot nytten er gunstig. Vanligvis etterlater innkjøp av slike spesialbøker nemlig en smertelig hull i budsjettet.

\section{Anbefalt lesing om rotatormansjetten}

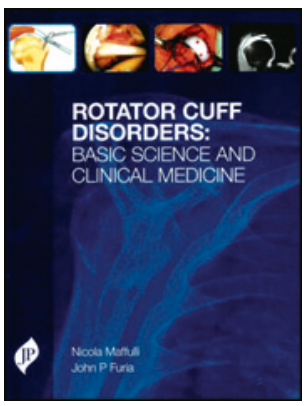

Nicola Maffulli, John P. Furia

Rotator cuff disorders

Basic science and clinical medicine. 352 s, tab, ill. London: JP Medical Publishers, 2012. Pris GBP 75

ISBN 978-1-907816-08-6

Målet har vært å skrive en lettlest, men grundig bok som gir et overblikk over skader i rotatormansjetten. Det har lykkes.

Det kan virke smalsporet å lage en egen bok om en muskelgruppe. Imidlertid står rotatormansjetten sentralt i patologien ved mange skulderlidelser. Partiell reseksjon av akromion for å lage bedre plass til rotatormansjetten og sutur av rupturer i denne muskelgruppen er vanlige skulderinngrep i dag. Det er derfor på sin plass at det finnes egne bøker som kun omhandler skader av rotatormansjetten.

Boken er i A4-format, innbundet og trykt på godt papir. Kapitlene er veldig godt strukturert og pedagogisk oppbygd. Forfatterne balanserer godt mellom det som er etablerte prinsipper og temaer som fortsatt er under debatt i ortopediske miljøer. De mange illustrasjonene og fotografiene bidrar vesentlig til en god forståelse av emnet. Forfatterne tar oss gjennom den kirurgiske anatomien, rotatormansjettens biomekaniske funksjon og undersøkelsesteknikker. Før gjennomgangen av reparasjonsteknikker av partielle og fullstendige rupturer omtales også hvordan man best kan utrede skulderpatologi med radiologiske metoder. Boken er fra 2012 og er oppdatert på diskusjonen rundt ortobiologiske midler, som for eksempel bruk av trombocyttkonsentrat. For helhetens skyld hadde det vært nyttig om forfatterne hadde presentert en oversikt over de forskjellige suturmetodene som leverandører tilbyr i dag, men det er kun en liten anmerkning og trekker ikke ned det gjennomgående gode inntrykket boken gir.

Jeg kan absolutt anbefale denne til alle ortopeder som begynner med skulderkirurgi. Den vil også være nyttig for fysioterapeuter og manuellterapeuter som behandler pasienter med skulderlidelser. Et skulderartroskopiatlas kan den ikke erstatte, og den prøver heller ikke å være en lærebok om skulderartroskopi generelt. Men den vil gi en solid og oppdatert kunnskapsbasis for håndtering av de mest vanlige skulderskadene.

\section{Bodo Günther}

Kirurgisk avdeling

Stord sykehus 